\title{
METABOLIC STUDIES ON CHRONIC ULCERATIVE COLITIS
}

\author{
By C. STUART WELCH,1 MILDRED ADAMS AND E. G. WAKEFIELD \\ (From the Section on Biochemistry, The Mayo Foundation, and the Division of Medicine, The \\ Mayo Clinic, Rochester, Minn.)
}

(Received for publication August 17, 1936)

The object of this study was to obtain definite information on the metabolic status of patients who have severe chronic ulcerative disease of the colon, which is usually termed " chronic ulcerative colitis." To obtain this information we have made under controlled conditions extensive studies of the composition of the feces, urine, and food of three patients afflicted with this disease.

Case 1 was a man, aged thirty-five years, who had an acute and advanced degree of the disease which involved the entire colon. This patient weighed 120 pounds (54.4 $\mathrm{kgm}$.) and was 73 inches $(185.4 \mathrm{~cm}$.) in height. He had been in good health until six weeks prior to his admission to the hospital when he had begun to have diarrhea, cramps in the abdomen, and fever. He had lost 70 pounds $(31.8 \mathrm{kgm}$.). Proctoscopic examination showed that the rectum, rectosigmoid, and sigmoid flexure were extensively ulcerated, scarred, and bleeding. Microscopic and bacteriological examinations of the feces revealed nothing of known importance. The value for the hemoglobin was 12.6 grams per $100 \mathrm{cc}$. of blood. Three observations were made in this case. The periods of these observations were four days, four days, and two days respectively.

Case 2 was a woman, aged forty-three years, who had had chronic diarrhea for two years, and a recent exacerbation. This patient weighed 137 pounds $(62.1 \mathrm{kgm}$.) and was 63 inches $(160 \mathrm{~cm}$.) in height. She had lost sixteen pounds $(7.3 \mathrm{kgm}$.). The entire colon was involved in the ulcerating process. Proctoscopic examination revealed numerous ulcerations in the rectum and sigmoid flexure. Microscopic and bacteriological examinations revealed nothing of known significance in the feces. There was 11.7 grams of hemoglobin in each 100 cc. of blood. Two observations were made in this case. The periods of these observations were three days each.

Case 3 was a man, aged twenty-five years, who weighed 110 pounds $(49.9 \mathrm{kgm}$.) and was 67 inches $(170.2 \mathrm{~cm}$.) in height, who had had diarrhea for two years, at times with acute severe exacerbations. The rectum and sigmoid flexure were ulcerated, scarred, and bled easily. - The entire colon was involved in the diseased process. Microscopic and bacteriological examinations revealed nothing of known etiological significance in the feces. The value for the hemoglobin was 10.7 grams per $100 \mathrm{cc}$.

${ }^{1}$ Fellow in Surgery, The Mayo Foundation. of blood. The duration of the one period of observation in this case was six days.

\section{THE GENERAL PLAN OF STUDY}

Procedure for the intake. Cases 1 and 3 received a balanced adequate diet. There was no variation in the meals from day to day. The diet consisted of meat, milk, cream, eggs, butter, rice, potato, fruits and vegetables. Three meals were given daily. Sodium chloride was added to the diet in weighed amounts. Distilled water was used for cooking and was given by mouth in measured amounts daily. The monotony of this unchanged diet was tolerated for as long as two weeks and in neither case did estimations have to be made for food unconsumed. An analysis of a twenty-four hour diet was made. Case 2 was unable to eat as great an amount of food as were Cases 1 and 3, and she could not be depended on for any regularity of consumption. Accordingly, she was allowed to select her diet, and the same amounts of food which she consumed daily were analyzed. Her. food was of the same general nature as that which was fed to the other two patients.

Analysis of foods. Analyses for nitrogen by the Kjeldahl method, fat (16), and chloride were made on a ground wet suspension of the food. An aliquot was dried and ground for determination of total solids and the amount of water. From this ground preparation, an ash was made in platinum dishes, using a muffle furnace, the temperature of which was kept below $550^{\circ} \mathrm{C}$. Quantitative determinations of sodium, potassium, calcium, magnesium, and phosphorus were made on a hydrochloric acid extract of this ash. The total caloric value and the carbohydrate content of the foods were estimated from the tables of Sherman (18).

The urine was preserved with thymol and kept on ice. Daily estimations of the amount of creatinine were made as an additional check on the ac- 
curacy of collections. Quantitative determinations of chloride, nitrogen, and inorganic phosphorus were made directly on the urine. An ash was prepared for the determination of sodium, potassium, calcium, and magnesium.

The feces were collected in periods corresponding to a known intake of food, which were determined by charcoal markers. In some instances, daily separation of the feces was made; in others, several days were allowed to elapse before separation. For accuracy and convenience, certain of the analyses were done on two-day mixtures of feces, while others were done on three-day, fourday, and six-day mixtures. From six to twentyfive rectal discharges during twenty-four hours produces a great mass of feces. The collection of the large quantity of feces varied according to the condition of the patient. Case 1 had an incontinent anus which necessitated special collecting arrangements. To accomplish this, a clean rubber pad was kept underneath the patient at all times. Dejecta were then washed from the pad into suitable containers with known amounts of distilled water. Case 2 was able to use a suitable enameled bedpan. The collection of feces of Case 3 was made by the use of a specially constructed commode which permitted a direct collection of the feces in glass containers.

Blood. Various chemical and hematological determinations were made on the blood of these patients; the results of these determinations will be considered later.

Physical characteristics of the feces. The

TABLE I

Physical properties of the feces

\begin{tabular}{|c|c|c|c|c|c|c|}
\hline & \multicolumn{3}{|c|}{ Case 1} & \multicolumn{2}{|c|}{ Case 2} & \multirow{2}{*}{$\frac{\underset{3}{\text { Case }}}{\left[\begin{array}{c}\text { Pe- } \\
\text { riod } \\
1\end{array}\right.}$} \\
\hline & $\underset{1}{\mathrm{Pe}-}$ & 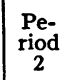 & $\underset{3}{\stackrel{P e}{\text { riod }}}$ & 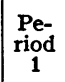 & $\underset{2}{\mathrm{Pe}-}$ & \\
\hline $\begin{array}{l}\text { Total weight of feces, } \\
\text { grams* } \ldots \ldots \ldots \ldots \\
\text { Total dry substance, } \\
\text { grams* } \ldots \ldots \ldots \ldots \\
\text { Total water, grams } \ldots \ldots \\
\text { Percentage of water } \ldots \ldots \\
\text { Percentage of dry feces } \ldots \\
\text { Average number of daily } \\
\text { dejecta } \ldots \ldots \ldots \ldots \ldots \ldots\end{array}$ & $\begin{array}{r}745 \\
84 \\
661 \\
89 \\
11 \\
22\end{array}$ & \begin{tabular}{|r}
902 \\
\\
91 \\
811 \\
90 \\
10 \\
24
\end{tabular} & $\begin{array}{r}1019 \\
101 \\
918 \\
90 \\
10 \\
21\end{array}$ & $\begin{array}{r}489 \\
72 \\
417 \\
85 \\
15 \\
21\end{array}$ & $\begin{array}{r}383 \\
53 \\
330 \\
86 \\
14 \\
17\end{array}$ & \begin{tabular}{|r}
363 \\
30 \\
333 \\
92 \\
8
\end{tabular} \\
\hline
\end{tabular}

* Grams excreted daily. weight of the feces excreted daily by these patients was excessive (Table I). For example, the first patient excreted from 745 grams to 1019 grams (90 per cent water) per day during the observation. The total dry weight, which was greater than normal, however, in each period, varied from 84 grams to 101 grams. In Cases 1 and 2 the values for total weight of the feces excreted daily and the weight of the dry substance were greater than they were in Case 3 . The colon of Case 1 was much more extensively diseased than were the colons of Cases 2 and 3 . There was gross blood and some pus in each of the dejecta of Cases 1 and 2 . No undigested food was seen at any time; each stool was examined grossly. Gross blood occasionally was noted in the feces of Case 3.

Chemical analysis of food, urine and feces. The results of the quantitative analysis of the food, urine, and the feces during the periods of observation will be considered together. In Table II the data have been recorded and a balance has been indicated. These results are expressed in average number of grams ingested or excreted daily. References to the methods used will be found in the tables.

Excretion of organic material. The presence of a daily fecal excretion of nitrogen far in excess of normal constitutes one of the most interesting findings of these observations. This loss of nitrogen from the body through the feces has not, however, resulted in a net loss of nitrogen or a considerably negative nitrogen balance in Case 1 . During the two months that Case 1 was observed after this study, the course was one of slow improvement, gain in body weight and improvement in health. The mechanism for conservation of body protein is evidenced by the low values for the total nitrogen excreted in the urine daily.

It has been indicated that Case 2 was unable to consume a satisfactory quantity of protein. During Period 1, an average of 4.69 grams of nitrogen per day was ingested in contrast to the total daily consumption of 12.61 grams of nitrogen by Case 1 . During Period 1, the total excretion of nitrogen in the urine was 4.03 grams daily in Case 2. Obviously, the patient was existing on a low nitrogen catabolism. Examination of the nitrogen partition products of the urine excreted 
TABLE II

Results of analysis of food, urine, and feces in three cases of chronic ulcerative colitis, expressed in grams per day

\begin{tabular}{|c|c|c|c|c|c|c|c|c|c|c|c|c|c|c|c|}
\hline & \multirow{2}{*}{ Intake } & \multicolumn{3}{|c|}{ Output } & \multirow{2}{*}{$\begin{array}{l}\text { Balance } \\
\text { or dif- } \\
\text { ference }\end{array}$} & \multirow{2}{*}{ Intake } & \multicolumn{3}{|c|}{ Output } & \multirow{2}{*}{$\begin{array}{l}\text { Balance } \\
\text { or dif- } \\
\text { ference }\end{array}$} & \multirow{2}{*}{ Intake } & \multicolumn{3}{|c|}{ Output } & \multirow{2}{*}{$\begin{array}{l}\text { Balance } \\
\text { or dif- } \\
\text { ference }\end{array}$} \\
\hline & & Urine & Feces & Total * & & & Urine & Feces & Total & & & Urine & Feces & Total & \\
\hline \multicolumn{16}{|c|}{ Case 1} \\
\hline $\begin{array}{l}\text { Nitrogen } \dagger \ldots . \\
\text { Fat } \ddagger . . . . . . . \\
\text { Sodium } \$ . . . \\
\text { Potassium } \| . . \\
\text { Calcium } \| . \ldots \\
\text { Magnesium } \| . \\
\text { Chloride } \pi . \\
\text { Phosphorus } \\
\text { Water } \dagger+. . . .\end{array}$ & \multicolumn{5}{|c|}{ Case 3} & & & & & & & & & & \\
\hline 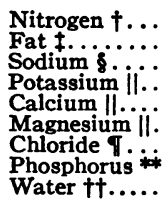 & \begin{tabular}{|l}
11.49 \\
90.4 \\
2.05 \\
2.83 \\
0.963 \\
0.208 \\
3.69 \\
1.32 \\
3018
\end{tabular} & $\begin{array}{l}6.96 \\
0.593 \\
0.313 \\
0.162 \\
0.041 \\
1.51 \\
0.446 \\
1264\end{array}$ & \begin{tabular}{|l|}
2.99 \\
5.6 \\
0.44 \\
1.17 \\
0.644 \\
0.126 \\
0.56 \\
0.555 \\
333
\end{tabular} & \begin{tabular}{|l|}
9.95 \\
1.03 \\
1.48 \\
0.806 \\
0.167 \\
2.07 \\
1.00 \\
1597
\end{tabular} & $\begin{array}{c}+1.54 \\
+84.8 \\
+1.02 \\
+1.35 \\
+0.157 \\
+0.041 \\
+1.62 \\
+0.32 \\
+1421\end{array}$ & & & & & & & & & & \\
\hline
\end{tabular}

* In urine and feces.

+ Determined by Kjeldahl's method.

¥ Determined by Saxon's modification (16) of Fowweather's method.

$\$$ Determined by method of Butler and Tuthill (2).

II Determined by method of Tisdall and Kramer (21).

T Chloride in urine was determined by Folin's (8) modification of the Voldhard method; chloride in food and feces was determined by method of Peters and Van Slyke (15).

** Determined by method of Fiske and Subbarow (4).

t† Includes water in food.

in one day (Table III) reveals that the value for the urea nitrogen plus that for the ammonia nitrogen was reduced. The total value for the urea nitrogen and ammonia nitrogen amounted to only 60.8 per cent of the total nitrogen. The values for the creatinine, creatine, uric acid, and amino-acid nitrogen were not greatly increased. There was a measurable increase in the value for ammonia nitrogen. Gamble, Ross and Tisdall (10) have demonstrated in their studies on fasting children that such an increase in the value for ammonia nitrogen accompanies efforts to conserve the total base of the body. In Case 2, there was considerable loss of base through the intestinal tract, which necessitated marked curtailment in the excretion of base in the urine and notably the excretion of sodium. The excretion of nitrogen in the feces reached a considerable magnitude ( 7.42 grams daily in Period 1 and 6.15 grams daily in Period 2). These amounts represent 64.8 per cent and 56.9 per cent respectively of the total output during Period 1 and Period 2. The total excretion of nitrogen in Period 1 was 6.76 grams more than was ingested. In Period 2, the amount of total nitrogen excreted was 6.61 grams more than was ingested. It is apparent that the large negative nitrogen balance resulted from the excessive amount of this substance in the feces, which 
TABLE III

Average daily values for nitrogen partition products in the urine

\begin{tabular}{|c|c|c|c|c|}
\hline \multirow[b]{2}{*}{ Partition products } & \multicolumn{2}{|c|}{ Case 2} & \multicolumn{2}{|c|}{ Case 3} \\
\hline & Grams & $\begin{array}{c}\text { Per- } \\
\text { cent- } \\
\text { age of } \\
\text { total } \\
\text { nitro- } \\
\text { gen }\end{array}$ & Grams & $\begin{array}{c}\text { Per- } \\
\text { cent- } \\
\text { age of } \\
\text { total } \\
\text { nitro- } \\
\text { gen }\end{array}$ \\
\hline 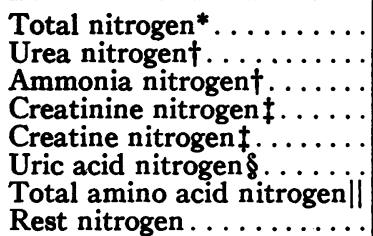 & \begin{tabular}{|l|}
3.26 \\
1.32 \\
0.663 \\
0.232 \\
0.157 \\
0.151 \\
0.192 \\
-0.545
\end{tabular} & $\begin{array}{r}40.5 \\
20.3 \\
7.1 \\
4.8 \\
4.6 \\
5.9 \\
16.7\end{array}$ & $\begin{array}{l}7.0 \\
4.65 \\
0.803 \\
0.378 \\
0.079 \\
0.212 \\
0.222 \\
+0.656\end{array}$ & $\begin{array}{r}66.0 \\
11.0 \\
5.4 \\
1.1 \\
3.0 \\
3.2 \\
9.4\end{array}$ \\
\hline
\end{tabular}

* Determined by method of Kjeldahl.

+ Determined by the Van Slyke and Cullen modification (23) of Marshall's method.

‡ Determined by method of Folin (5) (boiling with picric acid).

$\$$ Determined by the method of Folin and Wu (6); Folin and Marenzi ( 7 ).

II Determined by the Van Slyke (22) volumetric method.

was approximately five or six times that found in normal feces. In this case we have concrete evidence that a large portion, if not all, of the fecal nitrogen is contributed to the dejected mass by the body itself, presumably from the elimination of body tissues and blood in the colon, inasmuch as during both periods of observation the daily output of nitrogen in the feces exceeded the amount of nitrogen ingested.

In Case 3, there was a positive balance for nitrogen; 1.54 grams more nitrogen was ingested than was excreted. This net gain of nitrogen in the body occurred while 2.99 grams of nitrogen were excreted daily in the stool. This patient did not excrete as large an amount of nitrogen in the feces as did Cases 1 and 2. It has been previously noted that only occasionally was gross blood found in the stools in Case 3 and that the number of daily rectal discharges was less than in Cases 1 and 2. There was a reduction in the urinary excretion of nitrogen just as there was in Cases 1 and 2. The amount of nitrogen ingested daily was 11.49 grams and the amount excreted daily in the urine was 6.96 grams. This indicates that a positive balance was made possible by the reduction in the urinary excretion of nitrogen. To contrast these data with those of a normal adult who excretes in the urine as nonprotein nitrogen
TABLE IV

Average daily values for amount of fat in food and feces

\begin{tabular}{|c|c|c|c|c|c|c|c|c|c|}
\hline \multirow[b]{2}{*}{ Case } & \multirow{2}{*}{$\begin{array}{l}\text { Perlod } \\
\text { of ob- } \\
\text { serva- } \\
\text { tion }\end{array}$} & \multicolumn{3}{|c|}{ Fat in food } & \multicolumn{5}{|c|}{ Fat in feces 4} \\
\hline & & Grams & $\begin{array}{c}\text { Neu- } \\
\text { tral } \\
\text { fat }\end{array}$ & $\begin{array}{l}\text { Fatty } \\
\text { acids }\end{array}$ & Grams & $\begin{array}{c}\text { Neu- } \\
\text { tral } \\
\text { fat }\end{array}$ & $\begin{array}{l}\text { Fatty } \\
\text { acids }\end{array}$ & \begin{tabular}{|c|} 
Per- \\
centage \\
of that \\
ingested
\end{tabular} & $\begin{array}{l}\text { Percentage } \\
\text { of total dry } \\
\text { substance } \\
\text { of feces }\end{array}$ \\
\hline \multirow[t]{3}{*}{1} & 1 & 150.3 & $\begin{array}{c}\text { per } \\
\text { cent } \\
95.6\end{array}$ & $\begin{array}{c}\text { per } \\
\text { cent } \\
4.4\end{array}$ & 8.4 & $\begin{array}{c}\text { per } \\
\text { cent } \\
42.8\end{array}$ & $\begin{array}{c}\text { per } \\
\text { cent } \\
57.2\end{array}$ & 5.6 & 10.0 \\
\hline & 2 & 150.3 & 95.6 & 4.4 & 8.8 & 46.7 & 53.3 & 5.9 & 9.7 \\
\hline & 3 & 150.3 & 95.6 & 4.4 & 11.2 & 47.0 & 53.0 & 7.5 & 11.1 \\
\hline \multirow[t]{2}{*}{2} & 1 & $\overline{55.8}$ & $\overline{97.1}$ & 2.3 & 9.1 & 26.9 & 73.1 & 16.3 & 12.7 \\
\hline & 2 & 34.9 & 95.9 & 4.1 & 5.0 & 38.9 & 61.1 & 14.3 & 9.4 \\
\hline 3 & 1 & 90.4 & 96.9 & 3.1 & 5.6 & 45.3 & 54.7 & 6.2 & 18.8 \\
\hline
\end{tabular}

* Determined by Saxon's modification (16) of Fowweather's method.

$\dagger$ No soaps were present.

an amount equivalent to that which he ingests, suggests to us that this loss of nitrogen in chronic ulcerative colitis is not the result of unabsorbed food $(1,13,17,19)$ but is attributed to a loss of body tissue.

The amount of fat in feces and food have been separately recorded in Table IV. The largest amount of fat eliminated daily occurred in Case 1 in the third period. The amount eliminated represented only 7.5 per cent of the fat ingested. Case 2 consumed an average of $\mathbf{5 5 . 8}$ grams and 34.9 grams of fat in Periods 1 and 2, respectively. The fat eliminated during these periods represented 16.3 per cent and 14.3 per cent respectively of that ingested. Although the actual values for fat in the feces of Case 2 are not large, the small amount of fat ingested produces a calculation for an elimination that is out of proportion to the amount ingested. It is usually estimated that fecal fat amounts to 5 or 10 per cent of the fat ingested (14), although fecal fat is probably not, under normal conditions, derived from undigested and absorbed food. Hill and Bloor (11) have demonstrated that fecal fat is quite constant for a given individual and that it is dependent on the diet. Sperry (20) has demonstrated that the excretion of fat by dogs which have been deprived of fat in their diet remains constant. Fowweather (9) has determined that if the amount of fat in stools comprises more than 28 per cent by weight of the total dry substance the condition is abnormal. In none of these three cases did the fat in the feces 
reach such a quantity. In Case 3 the quantity of fat in the feces amounted to 18.8 per cent of the total dry substance. This was the largest value obtained in any of these observations. In contrast to the fecal excretion of nitrogen, there was no evidence of an increased elimination of fat in the feces in any of these cases.

These three cases of chronic ulcerative colitis had a normal metabolism of fat and an abnormal metabolism of nitrogen. In Case 3 the excretion of nitrogen in the feces was only slightly increased. The absence of a markedly increased excretion of nitrogen in the feces in this case is in contrast to the fecal excretion of nitrogen in Cases 1 and 2. In the latter cases there was a normal metabolism of fat in the presence of a grossly abnormal nitrogen metabolism. There were two salient findings in Case 3: (1) there was a definite increase in the excretion of nitrogen in the feces, which occurred in the face of a net gain of nitrogen to the body, and (2) the losses of nitrogen from the body through the feces were not excessive. Apropos of this there were fewer bowel movements, than there were in Cases 1 and
2 , and the feces did not contain much blood; these features indicate the mildness of the disease process in the colon. The fewer number of bowel movements in Case 3 tempts one to make a most obvious inference, namely, that in Cases 1 and 2 in which large amounts of nitrogen were found in the feces, the food has been rushed through the digestive tract and has not had an opportunity to be absorbed. However, the frequent defecations present in Cases 1 and 2, did not hinder the digestion and absorption of fat. The fact that these two patients normally absorbed fat gives the impression that the number of defecations in cases of ulcerative colitis does not have an important relation to the passage of food through the gastrointestinal tract but that the metabolic disturbances have a direct relation to the degree of disease process in the colon which permits the loss of blood and other body fluids and tissues.

The results of the analyses for the inorganic constituents of food, urine and feces have been recorded in Table II. The distribution of the daily output of inorganic constituents in the urine and feces has been recorded in Figure 1.

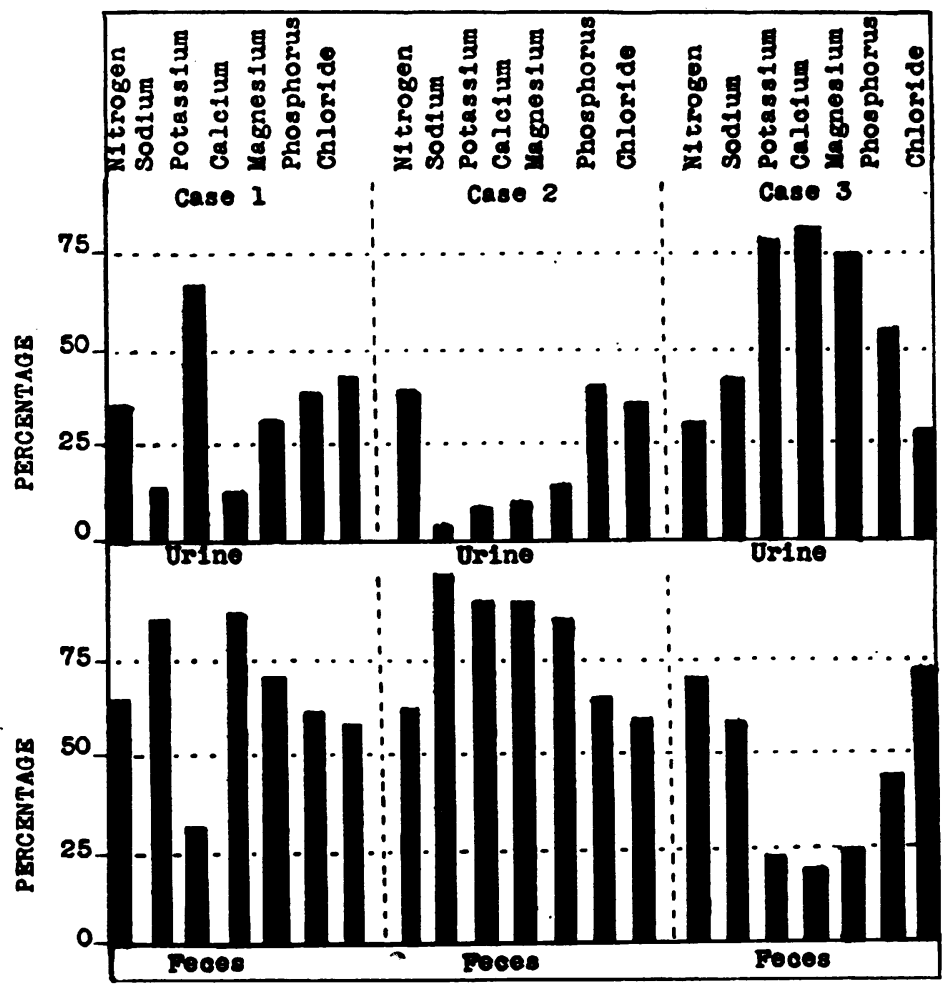

Fig. 1. Percentage Distribution of Nitrogen and Inorganic Constituents in Urine and Feces 
The amounts of sodium excreted daily in urine and feces were less than the amounts ingested in Cases 1 and 3. This apparently is a positive sodium balance. Excretion of sodium in the urine and feces in Case 2 exceeded the amount ingested.

The percentage distribution of sodium in the feces and urine is shown in Figure 1. It is apparent that the excretion of sodium in the feces greatly exceeds that in the urine. In Case 1, 73.8 per cent of a total of 2.33 grams were eliminated in the feces in Period 1. The output of sodium in the feces also was greater in each of the other two cases. However, the most marked example of the relative increase in the fecal excretion of sodium occurred in Case 2 (Figure 1). The urinary excretion of sodium was relatively low in all cases. Feces usually contain only 1 to 2 per cent of the total sodium excreted daily (14). In these cases, as much as 97.5 per cent of the total sodium eliminated per day was found in the feces. An inquiry into the cause of this increase in the excretion of sodium in the feces leads to the suspicion that it was the result of the large losses of intestinal fluids. The total amount of water lost daily varied from 918 grams to 330 grams and, in general, the more water eliminated, the more sodium was present in the feces.

In a previous paper by Welch, Wakefield, and Adams (25), it has been indicated that fluid that has a total base concentration of approximately 150 to 170 m.eq. per liter, 120 to 130 m.eq. of which are made up of sodium, is delivered to the colon to be absorbed. It was further indicated that losses from an ileac stoma caused a decrease in the excretion of sodium in the urine. This decrease in the urinary excretion of sodium demonstrates that there is a compensatory mechanism designed to maintain the total electrolyte of the body fluids near a constant value. The excretion of sodium in the feces of these patients is comparable to that observed in a case in which the patient has an ileac stoma. Intestinal fluid was delivered to the colon from the small intestine in quantities which could not be absorbed because of the diseased mucous membrane of the bowel. This fluid was therefore passed along and lost with the feces.

The distribution of total output of potassium in the urine and feces is also abnormal because the total amount of daily feces is greater than normal. In Case 2, as much as 92.7 per cent of the total potassium eliminated in Period 2 occurred in the feces. Case 3 was in positive "balance." There was evidence of a marked potassium retention. We have been unable to determine whether or not the fecal excretion of potassium parallels the fecal solids. However, the excretion of sodium is proportional to that of water. The increase in the amount of fecal potassium in these cases would seem to be the result of augmentation of the feces by desquamated epithelium, tissue from the ulcerated wall of the colon, and blood.

The excretion of calcium in these cases was largely by the intestinal route; from 80 to 93 per cent of the total daily excretion of calcium was found in the feces in Cases 1 and 2 . The calcium excreted in the urine was markedly decreased in all cases. It would seem that in Cases 1 and 2 more calcium than normal was lost through the gastro-intestinal tract and that the values for the blood calciums were also low. The excretion of magnesium and phosphorus was mainly through the feces.

Losses of chloride in the feces were substantial and paralleled to some extent the losses of sodium. The loss of sodium through the intestinal tract, however, was relatively greater than was the loss of chloride. This may be explained by the fact that the intestinal fluid contains relatively less fixed acid than it does fixed base. From 73.1 to 27 per cent of the total chloride was excreted by the intestinal route. In some of the periods, the chloride balance was negative.

The values obtained for serum sodium and the chloride in the plasma (Table V) indicate that the continuous loss of intestinal fluid resulted in a lowering of the concentration of these substances. Values for serum sodium were found to be consistently low (from 297 to $306 \mathrm{mgm}$. per $100 \mathrm{cc}$.). The values for the chloride were as low as $300 \mathrm{mgm}$. per $100 \mathrm{cc}$. of plasma on one occasion. The large losses of calcium in the feces also has resulted in low values for this mineral. The concentrations of the other inorganic substances in the blood were normal. 
TABLE V

Results of analysis of serum and plasma

\begin{tabular}{|c|c|c|c|c|c|c|c|}
\hline \multirow{2}{*}{ Cas } & \multirow{2}{*}{$\begin{array}{c}\text { Period } \\
\text { of obser- } \\
\text { vation }\end{array}$} & \multicolumn{5}{|c|}{ Blood serum } & \multirow{2}{*}{$\begin{array}{c}\text { Blood } \\
\text { plasma } \\
\text { chlor- } \\
\text { ide II }\end{array}$} \\
\hline & & ${ }_{\text {cium }}^{\text {Cal- }}$ & $\begin{array}{c}\text { So- } \\
\text { dium } †\end{array}$ & $\begin{array}{l}\text { Potas- } \\
\text { sium } \ddagger\end{array}$ & $\begin{array}{l}\text { Magne- } \\
\text { sium } \mp\end{array}$ & $\begin{array}{c}\text { Phos- } \\
\text { phorus \& }\end{array}$ & \\
\hline \multirow[t]{2}{*}{2} & 1 & $\begin{array}{c}\text { mgm. } \\
\text { per. } \\
100 \text { cc. } \\
8.3\end{array}$ & $\begin{array}{c}\text { mgm. } \\
\text { per } \\
100 \mathrm{ccc} . \\
305\end{array}$ & $\begin{array}{c}\text { mgm. } \\
\text { per } \\
100 \text { cc. } \\
15.8\end{array}$ & $\begin{array}{c}\underset{\mathrm{mgm} .}{\mathrm{mer}} \\
100 \mathrm{ccc} \\
2.2\end{array}$ & $\begin{array}{c}\text { mgm. } \\
\text { per } \\
100 \text { cc. } \\
3.1\end{array}$ & $\begin{array}{c}m g m . \\
\text { per. } \\
100 \text { cc. } \\
310\end{array}$ \\
\hline & 2 & 8.8 & 297 & 18.7 & 2.3 & 4.0 & 300 \\
\hline \multirow[t]{2}{*}{3} & 1 & 8.8 & 299 & 20.9 & 2.1 & 4.1 & 337 \\
\hline & 2 & 9.3 & 306 & 19.3 & 2.1 & 4.3 & 347 \\
\hline
\end{tabular}

* Determined by method of Clark and Collip (3).

+ Determined by method of Butler and Tuthill (2).

$\ddagger$ Determined by method of Kramer and Tisdall (12).

$\$$ Determined by method of Fiske and Subbarow (4).

II Determined by method of Van Slyke (24).

\section{COMMENT}

The data obtained in the study of these three cases of chronic ulcerative colitis, which were of different degree of severity, has indicated that in general the metabolic disturbance took a definite direction. Considerable losses of important bodily substances have occurred in these cases through excretion in the feces. The elimination of nitrogen in the feces may reach considerable magnitude and the amount of nitrogen excreted daily would seem to be directly proportional to the severity of the ulcerative process in the colon rather than to the amount ingested in the food. In the presence of great losses of nitrogen in the feces there was a small urinary excretion of nitrogen in comparison to the intake of nitrogen in Cases 1 and 3. A decrease in the urinary excretion of nitrogen is seen in conditions of lowered nitrogen intake, starvation in the growing child, recovery from starvation, and during lactation. In many of these states there is a low value for the blood urea. A low value for the blood urea is a consistent observation in cases of severe chronic ulcerative colitis. In such cases, the concentration of urea in the blood varies from 8 mgm. to $20 \mathrm{mgm}$. per $100 \mathrm{cc}$. The metabolism of nitrogen in ulcerative colitis, with its evidence of diminished protein catabolism, would seem to be comparable to that observed in the lactating animal in which the source of the nitrogen excreted in the milk is body tissue. In cases of chronic ulcerative colitis, the nitrogen is lost in exudates and in blood from the ulcerative surface of the colon. In these conditions, the first claim for protein absorbed is for synthesis of tissue as long as there is an adequate amount of fat and carbohydrate available for. combustion.

The excretion of fat in the feces in these cases of ulcerative colitis was not in excess of that seen in normal subjects under the same conditions of intake. The fat of the food ingested by these subjects was digested and absorbed as well as in healthy individuals, as far as can be ascertained.

The elimination of water in the feces was considerable in Case 1, less in Case 2, and least in Case 3.

We feel that the rôle which the diarrhea plays in conditioning deficiency states in cases of chronic ulcerative colitis by virtue of decreasing the absorption of food through rapid transit or through changes in the character of the small intestine has been overestimated.

It would seem that the greatest need of the body of a subject with ulcerative colitis is for protein. It would also seem to be of advantage to supply in abundance those minerals lost in excess in the feces and depleted from the body, as evidenced by their lowered concentration in the blood serum.

\section{BIBLIOGRAPHY}

1. Bargen, J. A., and Victor, Sister M., Diet in intestinal disorders. J. A. M. A., 1931, 97, 151.

2. Butler, A. M., and Tuthill, E., An application of the uranyl zinc acetate method for determination of sodium in biological material. J. Biol. Chem., 1931, 93, 171.

3. Clark, E. P., and Collip, J. B., A study of the Tisdall method for the determination of blood serum calcium with a suggested modification. J. Biol. Chem., 1925, 63, 461.

4. Fiske, C. H., and Subbarow, Y., The colorimetric determination of phosphorus. J. Biol. Chem., 1925, 66, 375.

5. Folin, O., On the determination of creatinine and creatine in urine. J. Biol. Chem., 1914, 17, 469.

6. Folin, O., and $\mathrm{Wu}, \mathrm{H}$., A revised colorimetric method for determination of uric acid in urine. J. Biol. Chem., 1919, 38, 459.

7. Folin, O., and Marenzi, A. D., The preparation of uric acid reagent completely free from phenol reagent. J. Biol. Chem., 1929, 83, 109.

8. Folin, O., Laboratory Manual of Biological Chemistry. D. Appleton-Century Co., New York, 1934, 5 th ed. 
9. Fowweather, F. S., The determination of the amount and the composition of the fat of faeces. II. The composition of the fat of the faeces of the normal adult, as ascertained by the "wet" method, together with some results in certain pathological conditions. Brit. J. Exper. Path., 1926, 7, 15.

10. Gamble, J. L., Ross, G. S., and Tisdall, F. F., The metabolism of fixed base during fasting. J. Biol. Chem., 1923, 57, 633.

11. Hill, Elsie, and Bloor, W. R., Fat excretion. J. Biol. Chem., 1922, 53, 171.

12. Kramer, B., and Tisdall, F. F., A clinical method for the quantitative determination of potassium in small amounts of serum. J. Biol. Chem., 1921, 46, 339.

13. Lehmann, C., Mueller, F., Munk, I., Senator, H., and Zuntz, N., Untersuchungen an zwei hungernden Menschen. Virchows Arch. f. path. Anat., Supp., 1893, 131, 107.

14. Peters, J. P., and Van Slyke, D. D. Quantitative Clinical Chemistry. Volume I. Interpretations. Williams and Wilkins Co., Baltimore, 1931.

15. Peters, J. P., and Van Slyke, D. D. Quantitative Clinical Chemistry. Volume II. Methods. Williams and Wilkins Co., Baltimore, 1932.

16. Saxon, G. J., A method for the determination of the total fats of undried feces and other moist masses. J. Biol. Chem., 1914, 17, 99.

17. Schamberg, J. F., Kolmer, J. A., Ringer, A. I., and
Raiziss, G. W., Research studies in psoriasis. II. Protein metabolism in psoriasis. J. Cutan. Dis., 1913, 31, 802.

18. Sherman, H. C., Chemistry of Food and Nutrition. Macmillan Co., New York, 1932, 4th ed.

19. Smith, Millard, The minimum endogenous nitrogen metabolism. J. Biol. Chem., 1926, 68, 15.

20. Sperry, W. M., Lipid excretion. III. Further studies of the quantitative relations of the fecal lipids. J. Biol. Chem., 1926, 68, 357.

21. Tisdall, F. F., and Kramer, Benjamin, Methods for the direct quantitative determination of sodium, potassium, calcium and magnesium in urine and stools. J. Biol. Chem., 1921, 48, 1.

22. Van Slyke, D. D., Improved methods in the gasometric determination of free and conjugated aminoacid nitrogen in the urine. J. Biol. Chem., 1913, 16, 125.

23. Van Slyke, D. D., and Cullen, G. E., A permanent preparation of urease, and its use in the determination of urea. J. Biol. Chem., 1914, 19, 211.

24. Van Slyke, D. D., The determination of chlorides in blood and tissues. J. Biol. Chem., 1923, 58, 523.

25. Welch, C. S., Wakefield, E. G., and Adams, M., The function of the large intestine of man in absorption and excretion: study of a subject with an ileostomy stoma and isolated colon. Arch. Int. Med. (In press.) 